\title{
Thinking Technology Big Again. Reconsidering the Question of the Transcendental and 'Technology with a Capital T' in the Light of the Anthropocene
}

\author{
Pieter Lemmens ${ }^{1}$
}

Accepted: 10 December 2020 / Published online: 4 February 2021

(C) The Author(s) 2021

\begin{abstract}
This article has two general aims. It first of all critically reconsiders the empirical turn's dismissal of transcendentalism in the philosophy of technology, in particular through the work of Ihde and Verbeek, and defends the continuing relevance of the notion of the transcencental in thinking about technology today, illustrating this mainly through a reading of Stiegler's understanding of the human condition as a technical condition and his view of human (noetic) evolution as proceeding from a process of technical exteriorization. The crucial issue that is missed by postphenomenology and the empirical turn is that technology itself in its empiricity occupies the (periodically changing) place of the transcendental. It thus fails to consider the transcendental operativity of technical artifacts within its own empiricist stance. Secondly, it argues for the continuing importance and usefulness of the idea of Technology with a capital T, equally discarded by the representatives of the empirical turn, in particular against the emerging backdrop of the Anthropocene as the age of decisive anthropogenic forcing of the planet and the growing dominance of what has recently been called the technosphere in Earth system science. With Stiegler I show that a proper, inherent dynamic of technology must be acknowledged historically, anthropologically, techno-evolutionarily as well as (techno)phenomenologically. I conclude by demonstrating that our time of planetary crisis summons us to redirect our attention to technology from the empirical to the transcendental, and from the micro-level to the macro-level again.
\end{abstract}

Keywords Empirical turn · Transcendental $\cdot$ Postphenomenology $\cdot$ Anthropocene $\cdot$ Ihde Stiegler

\section{Introduction}

Nowadays widely and often uncritically accepted as a fait accompli among philosophers of technology, the so-called 'empirical turn' was first promoted in 2001 by the Dutch philosopher Hans Achterhuis, who noted that the most crucial distinction

Pieter Lemmens

p.lemmens@science.ru.nl

1 Institute for Science in Society, Radboud University Nijmegen, Nijmegen, Netherlands 
between contemporary American philosophers of technology-to wit, Albert Borgmann, Hubert Dreyfus, Andrew Feenberg, Donna Haraway, Don Ihde and Langdon Winner-and the so-called 'classic' philosophers of technology of mostly European provenance-that is tot say, Jacques Ellul, Martin Heidegger, Günther Anders, Hans Jonas, Arnold Gehlen, Karl Jaspers and Herbert Marcuse-was the fact that whilst the latter were engaged in thinking the historical and transcendental conditions that made technology possible and did not have much attention, apparently, for the real impacts of concrete technological developments on human culture and society, the former on the contrary explicitly focused on empirically analyzing the various ways in which all kinds of technologies manifest themselves in all kinds of ways in different societal and cultural contexts (Achterhuis 2001, 3).

Building on the terrain laid open by their European 'founding fathers', the American philosophers have directed their critical attention to empirically studying the development, the use and the effects of specific technical artefacts in specific daily use contexts, which cannot be reduced to the conditions that make this possible (ibid. 7). They have thereby collectively developed an empirical philosophy of technology as a correction to the transcendental if not transcendentalist approaches that characterize classic philosophy of technology. This empirical turn brings them close to the social constructivist approaches developed earlier in Science and Technology Studies (STS) under the influence of Thomas Kuhn's 1962 classic study in the philosophy of science, The Structure of Scientific Revolutions, although it must be said that Kuhn did not restrict himself to studying specific empirical-i.e., historical-cases but developed a general theory for understanding theoretical change in the natural sciences based on these historical case studies, i.e., his famous paradigm theory (Kuhn 1996).

Another habit present in the work of these classic philosophers of technology, congruent with their transcendental(ist) approaches, was that they tended to reify, essentialize or substantialize the process of technological development into some kind of autonomous force with a logic of its own and imposing itself on human societies in an unconditional and inevitable way, something deserving capitalization, like Heidegger's 'Essence of Technology' or Ellul's 'Technological Imperative'. This is the well-known 'Technology with a capital T' reproach (Ihde 1990, 6; Verbeek 2005, 4) that was another major motivation behind the empirical turn. As such, the two most important claims made by the empirical turn are that concrete technologies are not fully determined by their transcendental conditions and that there is not some kind of inherent logic toward increasing efficiency, domination, performativity or some other uncanny tendency present in technological development, but that it is a principally contingent and unpredictable process.

Since I have already dealt in some detail with the issue of the transcendental earlier (Lemmens 2017), I will here only touch upon it in the beginning, restricting myself mainly to Stiegler's understanding of it in contrast to Ihde's dismissal of it, but will then turn to both Ihde's and Stiegler's view on what Ihde has called 'Technology with a capital T'. I will argue for the continuing importance and usefulness of this notion, particularly against the emerging backdrop of the Anthropocene, understood here as an irreversible shift of the Earth System in which its fate is becoming entangled irrevocably with the fate of our technological civilization and that is to say with the global technical system. The general question is what this new geological condition entails for humanity's planetized technical condition-and vice versa. 


\section{Technology and the Question of the Transcendental in Ihde and Stiegler}

Don Ihde is certainly one of the most outspoken proponents of the empirical turn and obviously also one of the main inspirations behind Achterhuis' coining of the term. His postphenomenology has a decisively empirical orientation and resists any transcendental consideration. Ihde is typically-indeed archetypically-a philosopher of technology in the familiar sense as practiced by most of today's scholars associated with the international Society for the Philosophy of Technology (SPT), an organization that he co-founded in 1976. His work focuses on empirico-phenomenological analyses of particular technologies and is exclusively interested in technology as a specific or regional domain of objects. Beyond that, again, it is also suspicious if not outright aversive toward all-too-philosophical questions about the transcendental, the ontological and the metaphysical related to technology. Stiegler on the other hand is very much an allround philosopher in the classic sense almost of a maitre penseur, fond of grand style, high-altitude theorizing about what Heidegger called 'being as such and in its totality' and all the while driven by one fundamental question that is held to lie at the root of all philosophical problematics. And for Stiegler, this is precisely the question of technology, in a sense that is similar but certainly not identical to the way in which Heidegger asked the question of being, a question that, as we know, also in Heidegger's own thinking developed more and more into the question concerning technology.

Stiegler is not ultimately interested in detailed empirical analyses and certainly not 'micro-analyses' of specific technologies for the purpose of examining their specific effects on human beings or societal structures in specific use contexts. Although he definitely engages in such analyses in all of his publications (and even develops new digital technologies and practices together with his colleagues from the Institute for Research and Innovation (IRI) at the Centre Pompidou in Paris as well with the Ars Industrialis association ${ }^{1}$ ), they always serve as stepping stones toward a more general consideration of technology's impact on individuals, collectives and ultimately the human condition. It is true that his main attention is directed toward the current development of digital network technologies but his final interest goes toward understanding how technology as such - thought as the domain of the 'organized inorganic' originally supplementing the 'original lack of origin' [défaut d'origine] that is typical of the human as an 'organized organic' or biological yet as such indeterminate living being (Stiegler 1998, 16-7)-characterizes the human condition as such, understood in this sense as a thoroughly accidental and prosthetic condition (Stiegler 2017, 94). And he is most interested in the noetic and/or 'spiritual' dimensions of this condition, i.e., in the accidental technicity or prostheticity of the mind. Every noesis as well as every sensibility from which it proceeds is a tekhnesis, as he puts it succintly at times (Stiegler 2015, 31). The perception of meaning and the activity of knowing are possible only because of an articulation of the sense organs and the bodily organs more generally, in particular the nervous system, with technical organs, always operating in a context of social organ-izations.

With Stiegler, as I read him at least, I would here like to defend the existence of, and the lasting importance of what the empirical turn calls 'Technology with a capital T', albeit

\footnotetext{
1 See for instance the various 'ateliers' for the development of technologies of the self, of relational technologies and of an economy of contribution organized by the Ars Industrialis association: http://www.arsin dustrialis.org/
} 
not necessarily in the exact same way as it understands it itself. When Stiegler states in the very first sentence of the first volume of his still unfinished magnum opus Technics and Time, that 'the object of this work is technics, apprehended as the horizon of all possibility to come and of all possibility of a future' (Stiegler 1998, ix), he definitely, in my view, has what postphenomenology rejects as 'Technology with a capital $\mathrm{T}$ ' in mind and above all the transcendental function of technology in framing the horizon of the possible in the sense of the future understood in the Heideggerian sense as the projective dimension of our Dasein.

Technology is addressed inTechnics and Time as the condition of possibility of Dasein as time understood in the Heideggerian sense of a process of ecstatic-horizontal temporalization through which beings can come into being, including the being that Dasein itself is. ${ }^{2}$ And when Stiegler writes in the next paragraph in a Heideggerian vein that technics in this sense is 'the unthought' in that it has been repressed or forgotten by philosophy from its very origin up until now (Stiegler 1998, ix), it seems to me that it is precisely this transcendental functioning of technology that he intends, and that it as such echoes Heidegger's claim concerning being as the unthought of philosophy (Heidegger 1968, 76-7). For Stiegler though, contra Heidegger, our technical or accidental condition is more original as it were than our openness to being and all understanding of being; it first opens up and conditions this openness (Stiegler 2013, 106). And more generally all transcendence of beings toward their being is conditioned by technical artefacts that are indeed empirical but as interiorized or implicated in the cognitive or noetic existential structure of Dasein function as quasi-transcendental conditions of the possibility of all thinking. It is this technical constitution, which is thoroughly accidental, that marks all thinking as fundamentally fragile, and it is precisely this 'fragility of the spirit' (Stiegler \& Ars Industrialis 2014b, 81) as confronted with the current revolution of digital technologies in the context of what neoMarxists call cognitive and communicative capitalism-and a fortiori against the backdrop of the Anthropocene-that arguably forms the motivation as well as the greatest concern of Stiegler's whole philosophical enterprise ${ }^{3}$; a concern largely absent in postphenomenology, as it hardly perceives the problem as far as I can see.

To be sure, when technology comes to occupy the place of the transcendental, we have moved away from all 'classic' transcendentalism, which is subjectivistic and radically opposes the transcendental as a priori and the empirical as a posteriori. For Stiegler view (and here he somehow concurs with postphenomenology but goes much further) that which was called the transcendental subject from Kant to Husserl is itself constituted by what it constitutes, and that is to say by technical objects or what Stiegler calls tertiary retentions, by which he means the artificial memory supports that underlie all life of the mind and without which it would lose any substance and durability (Stiegler 2011a, 80).

\footnotetext{
2 This process of temporalization is rethought in a Simondonian fashion as a process of psychic and collective co-individuation that is supported by and 'surfs' as it were on an underlying and pervasive process of technical individuation, but I cannot go into this here (cf. Stiegler 2012).

3 As Stiegler writes in a 'notice to the reader' preceding the second volume of Symbolic Misery, the 'network of questions' that he pursues as a philosopher is above all 'a matter of honing weapons: of turning this network of questions into an arsenal of concepts to be used in conflict. [...] My books are intended to assist in conflicts [...]' (Stiegler 2015, 2). And the most important conflict today is 'the auto-destructive tendency of a hyper-industrial capitalism that has lost any notion of its own limits' and threatens to completely destroy the life of the mind, a tendency which philosophy-qualitate qua-should combat by supporting and strenghtening 'the counter-tendency which this tendency also inevitably harbours' (ibid., 3).
} 
This move goes against all classic phenomenology, Heidegger included, which treats technical objects as purely empirical and excludes them from the sphere of constitution. For Stiegler though, technical objects exactly constitute this sphere, yet they do so in their very empiricity. This means that technology must be understood as being both transcendental and empirical or more precisely as the empirical transcendental or as the aposterioric a priori-and that is to say as the a posteriori proceeding from a process of technical exteriorization becoming a priori through a process of technical interiorization, a technical a priori or 'a priori prostheticity' (ibid., 141).

As such the transcendental subject of the tradition is re-interpreted as not autonomously self-constituting anymore but as originally re-constituting itself in relation to a more primordial technical heteronomy in the sense, as Stiegler writes, 'that it is constructed only as an after-effect and that it is always caught in the problematics of its own re-constitution' (ibid.), an après-coup of a technological revolution or change of a technical system. This is why Stiegler prefers to talk about the technological transcendental as the a-transcendental in that it transcends the metaphysical dichotomy between the empirical and the transcendental altogether (ibid., 141, Stiegler 2009, 222, Stiegler 1998, 243). And since technological transformations consistently precede and overdetermine transformations at the psychic and social level, the technological transcendental opens a 'transcendental field without a subject', using an expression first introduced by Jean Hyppolite and later adopted by Derrida (Stiegler and Ars Industrialis 2009, 89). Or in still other terms: it is an a-subjective transcendental or a 'transcendentalism without a subject', as Paul Ricoeur has it (Ricoeur 1974, 89).

The process of technological transformation as the incessant production of technical artefacts or tertiary retentions is what Stiegler calls epiphylogenesis (Stiegler 1998, 140, Stiegler 2014b, 34). Briefly put, this is the process of technical inheritance that underlies human evolution and both generates and sustains the historical, ecstatic-horizontal mode of being of Dasein by allowing for the transmission of individual experiences [epi-], inscribed in technical objects, onto the species [phylo-]. And this is precisely what constitutes the technical dynamic of the what as a dynamic that is more original, Stiegler claims, than the existential dynamic of the who that is Dasein, because the latter only becomes possible on the basis of the former (Stiegler 1998, 243). The concept of epiphylogenesis as a dynamic of the organized inorganic which originally constitutes Dasein by possibilizing and potentializing the organic lifeform behind 'the human' toward an organo-logical existence, allows Stiegler to critically overcome the empirico-transcendental divide that still haunts Heidegger's existential analytic as well as his ontohistorical thought because of its failure or refusal to think technics appropriately. It is therefore also what would have allowed Heidegger to grasp the accumulative 'logic' and 'necessity' behind the succession of the epochs of being in the history of being as well as its very commencement, which coincides for Stiegler with the invention of the mnemotechnique of writing, through which epiphylogenesis becomes a process of grammatization. But I cannot further explore this here (cf. Stiegler 2014a, 49, 53f).

It is my convinction, and this will conclude my all-too-brief discussion of the transcendental here, that Stiegler's explicitly technologized conception of the transcendental is not amenable to the critique of transcendentalism which postphenomenology levels against all classic philosophies of technology (and I admit for fair enough reasons). In fact, Stiegler shares a similar critique. However, instead of simply dismissing the whole problematic of the transcendental or at least ignoring it theoretically, he continues to recognize the transcendental as the philosophical problematic par excellence and reconceptualizes it from an explicitly techno-logical perspective by showing that it is in fact shaped by the empirical in 
the form of technical artefacts functioning as the pros-thetic conditions of, to put it in Kantian terms, all syn-thetic a priori judgements (Stiegler 2011a, 141). So instead of reducing technical artefacts to their non-technical conditions of possibility, be they existential, social, cultural or ontological-as classic philosophers of technology have been accused of doing by postphenomenologists-Stiegler shows on the contrary how existence, society, culture and even our understanding of being are themselves conditioned by technology, i.e., by a technical system or milieu of tertiary retentions that renders human being-in-theworld in all its dimensions first of all possible (Stiegler 2017, 58).

It is interesting, on a final note, to point out that the opposition between 'AmericanDutch' postphenomenology and 'French' technophenomenology on the question of the transcendental to some extent relates to the famous 'analytic-continental split' in the history of philosophy since Kant. This is basically the split between Anglo-Saxon empiricism and Continental transcendentalism. It seems to me that postphenomenology's turn to the empirical and its dismissal of the transcendental relegates it to the former camp, which also makes that it risks losing its genuine phenomenological purport, since phenomenology is in principle a transcendental discipline (indeed it is transcendental or nothing). As such it risks becoming just a brand of Science and Technology Studies. Following Richard Rorty, arguably one of his heroes, Ihde emphatically shares a pragmatic, 'detranscendentalized, naturalized conception of philosophy' (Rorty 1991, 52) and accordingly assumes that we can simply leave metaphysics out of any consideration of technics, instead directing our attention in an allegedly unbiased and no nonsense way to concrete technical artefacts.

Although it is true that postphenomenology does not share traditional empiricism and transcendentalism's common inattention to the material supports of human perception and cognition, it largely fails to consider the transcendental or better a-transcendental operativity of these material supports within its own empiricist stance. ${ }^{4}$ This may also partly explain its lack of awareness for the need of a new critique of reason, as reason today is in the process of being re-conditioned at the moment by digital technologies. It may also account more generally for its failure to perceive the inherent dangers of the fact that the operations of the mind are now more and more delegated to digital machines that first of all serve the logistic and economic needs of capital and that are implemented 'essentially under the influence of American industry [...] with an 'industrial brutality' that threatens the life of the mind and even with the possibility of the "annihilation of consciousness" (Stiegler 2011a, 81).

\section{In Defence of 'Technology with a Capital T'}

Let us now turn to the issue of 'Technology with a capital T'. Whilst postphenomenology is perfectly happy with attributing 'inclinations' and 'intentions' and that is to say some kind of agency to concrete technical artefacts (Ihde 1990, 141), indeed even emphasizes the acknowledgement of such 'technological intentionalities' (ibid., 102) as one of its trademarks, it stubbornly refuses or so it seems to consider any such directionality at the systemic level of technology. And as already said, it flatly denies the existence of what it calls 'Technology with a capital T', by which it understands Technology in a

\footnotetext{
4 A certain way of incorporating transcendental considerations into postphenomenology can be found though, in my view at least, in Yoni Van Den Eede's attempts to enrich it with a 'media ecology' perspective inspired by the work of Marshall McLuhan (Van Den Eede 2017).
} 
somewhat caricatural way as a 'single or unified trajectory' (Ihde 1990, 144) imposing itself upon society with an inescapable and autonomous logic, or as Verbeek describes it, as 'an independent power that can alter culture drastically', is unstoppable and 'follows its own dynamic' (Verbeek 2005, 136). Such a view of technology is incompatible, so the argument goes, with the multistability and cultural-relativist understanding of technology embraced by postphenomenology (ibid.).

Of course it is hard to defend such an extremely substantivist and determinist view of technology as a kind of fate, I fully admit. Even Heidegger, often accused of a substantivist and determinist view, explicitly rejects such a conception when he writes that the destining behind enframing is 'never a fate that compels' but constitutes instead the very realm where our ontological freedom as Dasein is played out and put at stake (Heidegger 1977, 25). Beyond caricature therefore, I think it cannot be denied that there is a profound systemic dimension to technology that thoroughly conditions in an all-encompassing sense what we can do and can be in our contemporary world, that technological development is cumulative and that it thoroughly conditions if not overdetermines our existences to an ever larger extent-including of course the many freedoms it makes possible-and does so with an ever increasing intimacy, and indeed that it lays a claim upon us [Heidegger's call or Anspruch], an imperative that is felt ever more intensely by ever more people across the globe and finally that there is indeed a logic of perfectioning or what Jean-François Lyotard has called a 'performativity principle' (Lyotard 1984, 50) at work in what we call technological progress.

Perfectioning is the whole idea behind progress, without which it would make not much sense, and what it is ultimately aimed at is "total "rationalization" (Heidegger 1996, 103), principally achieved through the universal or 'consistent calculability of objects', which would be the 'answer', Heidegger explained, of technoscientific humanity to the 'call' of the principle of sufficient reason, as a call coming from Being urging Dasein to work toward the 'completeness of foundation' (ibid., 114), pursued through 'research \& development' [Forschung]. It is through informatization that this process of rationalization and securing of all that is proceeds, and to such an extent that it suffices to ensure humanity's dominance over the planet and even over the extra-planetary realms, as Heidegger states in The Principle of Reason (ibid., 118). As the German philosopher Peter Trawny rightfully observes in his book On Freedom. Technology. Capital. Medium, a Heideggerinspired onto-topological analysis of our current world system, technological development is driven by optimization as the improvement of the ratio between invested cause and achieved effect. This, he continues, 'is also how we usually experience it in our technologically organized day-to-day lives' and it 'is due to the fact that particular technologies are continually updated' (Trawny 2017, 22). Thus he argues that technology 'constitutes progress toward perfection, or progressive perfection' (ibid.). Who would want to deny this in our current world of imposed permanent innovation and mandatory constant updating of our technological environments? And who would still want to maintain that this can somehow be stopped or that it does not alter cultures drastically on a global scale and with increasing uniformity? What is it exactly that motivates postphenomenology to persist in flatly denying this? I must confess that this is a genuine riddle to me.

With Stiegler, or as I read him at least, I would like to defend the thesis that we have to hold on to considering 'Technology with a capital T' instead of restricting ourselves to studying technologies only empirically, yet to think it beyond Heidegger (and also beyond Ellul, Marcuse and the Jünger brothers) but to nonetheless take seriously and concede the power of at least the Heideggerian diagnosis of enframing, also as something that frames our very rationality itself (Stiegler 1998, 83). In Stiegler's work there are at least four ways 
in which a proper and quasi-autonomous logic and inherent dynamic of 'Technology with a capital $\mathrm{T}$ can be perceived to be at work: historically, anthropologically, techno-evolutionary and (techno)phenomenologically. I will briefly elaborate upon these four dimensions in a moment.

In general, technology evolves and its evolution is not driven by humans nor by physical or even biological principles but by a dynamic that partly inheres in technical artefacts but that also has a crucial systemic aspect. Yet it should not be conceived deterministically and in a naturalistic fashion as a fully autonomous and inherently negentropic force that naturally 'wants' all kinds of things from us and to which we can only adapt so as to serve its glorious flowering upon the planet and possibly beyond, which is how Kevin Kelly presents what he calls the 'technium' in his 2010 book What Technology Wants, which is a truly substantivist and essentialist perspective (but nonetheless an interesting one.) For Kelly, the technium is an inherently negentropic or, as he calls it, 'exotropic' force (Kelly 2010, 63). As Stiegler rightly argues though in my view, technology is inherently ambiguous in terms of its entropic and negentropic potentials (to be discussed briefly below). It is not an essence but on the contrary 'essentially accidental', to put it oxymoronically, and it is up to us to negotiate with it and adopt it wholesomely. Technology is moreover the compensation of an original default and this is its real driving force, a default of origin which increases and complexifies with each stroke of compensation, thereby becoming ever more unmanageable (Stiegler 2013, 15).

The first, historical dimension in Stiegler's view of technology basically derives from the work of historian of technology Bertrand Gille, who has shown that technology forms systems that evolve and every once and a while transform as a result of reaching their internal limits, causing disadjustment in the other systems (social, cultural, political, economic, etc.) and forcing them to re-adjust to the new technical conditions (Stiegler 1998, 31-3). Technical progress consists in progressive displacements of the limits of succeeding technical systems (ibid., 33). Gille's work focused in particular on industrial technology, which is characterized by an ever more intense process of permanent innovation that inevitably leads, Stiegler maintains, to 'a divorce, if not between culture and technics, at least between the rhythms of cultural evolution and the rhythms of technical evolution' (ibid., 15). Crucial here is the notion of 'technical systematicity' or the play of constraints imposed by the interdependencies between technical elements and the system at large (ibid., 35), which is not theorized at all in postphenomenology, indeed is almost fully neglected in its analysis of human-technology relations, focused as it is on the individual subject vis-à-vis individual technical objects. An explicit proof of the presence of an inherent dynamic in technological development is not offered by Gille though. For this, we need to take a look at the evolution of the human species.

The second, (paleo)anthropological dimension is based on André Leroi-Gourhan's theory of human evolution as techno-evolution, laid down first in L'Homme et la matière (1943) and Milieu et techniques (1945) and later in the two volumes of Le geste et la parole (1964-65). These books amply demonstrate the existence of transcultural, universal, and selectionist technical tendencies that traverse cultural entities, in which they get concretized as technical facts (ibid., 43). The process of anthropogenesis as technogenesis results from the dynamic coupling-and thus the co-evolution-of humans as organized organic matter and technical objects as organized inorganic matter, a process that is initially determined zoologically or better zoo-techno-logically but assumes an ethnological or ethno-techno-logical modality once the co-evolution of the human cortex and stone tool technology reaches a conclusion (i.e., with the Neanderthal) and it is the social group that becomes the differentiating factor in response to techno-evolution (Stiegler 2009, 70). The 
technical tendency is thought of as a principle of selection of the best technical forms and originates neither from the human nor from the laws of physics; it operates, according to Stiegler, 'down through time, by selecting forms in a relation of the human living being to the matter it organizes and by which it organizes itself, where none of the terms of the relation hold the secret of the other' (Stiegler 1998, 49; emphasis in the original). Analogous to the evolution of life, the evolution of technics is complexifying or negentropic and as such exhibits a certain directionality or 'teleologism' (Stiegler 1998, 54). As we will see below, however, techno-evolution is not inherently or automatically negentropic (as is life), it can also produce entropy.

The techno-evolutionary dimension is drawn from the work of Gilbert Simondon, who points out, focusing on the industrial period, that the evolution of technologies proceeds through a process of concretization that has an internal logic and in which the role of the human engineer is restricted to that of an anticipating operator facilitating the unfolding of inherent potentialities (ibid., 66-7). Concretization is the process through which technical objects-or more precisely: technical species or lineages-progressively 'overcome' their initally abstract nature as assemblages of independently functioning elements and become more and more concrete as a result of the gradual convergence or integration of functions, i.e., through the increasing functional synergy of the elements (ibid., 69). It is a process of individuation as a becoming individual or indivisible of the organization of technical objects, which makes them approach but never achieve the full concreteness of the living (ibid., 72). Simondon's extensive and detailed analyses of the evolution or ontogenesis of industrial technical objects demonstrates, according to Stiegler, that there is a 'technological necessity' at work in the process of industrialization, which he interprets as 'the sign of an immense power of the technical object over industrial society, of technical evolution in general over becoming in general, of the "technical system" over the "other systems", (ibid., 73). What Heidegger called enframing, Stiegler suggests, might be explained as just such a process of concretization, but then scaled up to the systemic level (Stiegler 1998, 80, $82-3) .5$

Finally, Stiegler's own technophenomenology theorizes what he calls the process of technical becoming or technical individuation, which rethinks the technical tendency (inspired by Leroi-Gourhan) as a process of technical exteriorization that continually traverses human societies, periodically and today chronically disrupting them and putting them into question, thereby both forcing and allowing them to create another societal structure, which basically consists in the transformation of this becoming into a new collective future understood as the projection of collective desire and as a process of psychosocial individuation. This process of technical becoming can very well be anticipated and even predicted according to Stiegler, provided one does not focus exclusively on the particular technical artefacts sedimented by this technical becoming (again: what Leroi-Gourhan calls the technical tendency), which can very well contradict its general direction in the short term, but instead focuses on the tendency itself (Stiegler and Ars Industrialis 2006, 109n4, Stiegler 2011b, 11-12, Stiegler 2010, 124).

What does postphenomenology actually oppose to such a view, which I have admittedly all-too briefly sketched here? Well, 'multistability', to be sure. This is a quality attributed to technical artefacts derived originally from Ihde's discoveries of the multistable appearence

\footnotetext{
5 Cf. 'the technical object lays down the law that is its own, it affirms an auto-nomy with regard to which, in the industrial age, the other layers of society must regulate themselves, with an actual possibility of negotiation' (ibid., 73).
} 
of visual images and simple optical illusions, not technologies nota bene, through variational analyses in his enjoyable 1977 book Experimental Phenomenology (Ihde 2012). It was only later applied in a post-phenomenological fashion to the functioning of technical artefacts in human-technology relations and technology-culture gestalts (Ihde 1990, 146). While it is true that enough interesting examples of multistability are presented in Ihde's and Verbeek's works, and even more so of course in the postphenomenological literature at large (e.g. Rosenberger and Verbeek 2015; Van Den Eede et al. 2017), it seems to me that these form an insufficient basis to justify the rather massive claim made by Ihde and Verbeek that there is no inherent dynamic at all to Technology or to the evolution of concrete technical artefacts (ibid., 159; Verbeek 2005, 101, 136).

Of course, there is no denying that a hammer and an Acheulean hand axe can be used as a weapon and undoubtedly as many other things besides (Ihde 1990, 70) or that New Guinean aboriginals employ sardine cans as headwear (ibid., 125; Verbeek 2005, 136), but this is rather trivial, if only for the fact that these sardine cans were introduced in a completely different cultural world or horizon of understanding, to use Heideggerian terms. ${ }^{6}$ Yet as Heidegger has pointed out in one of his latest texts, it is increasingly the fact that 'Being as presencing in the sense of calculable material [...] claims all the inhabitants of the earth in a uniform manner' and this means that even the so-called underdeveloped countries are moving 'into the realm of hearing of that claim of Being which speaks from the innermost core of technology' (Heidegger 2002, 7; my emphasis)-with the implication that horizons of understanding are increasingly homogenized all over the planet and 'deviant' uses of particular technical artifacts of the kind evoked by Ihde increasingly rare. Which is not to deny, of course, that such artifacts can still be adopted in various ways and so lead to alternative sociotechnical practices, but this occurs always under the decisive condition of enframing. With Stiegler, though, we can understand this conditioning also in a more ontical sense (that is to say as supported and sustained through accumulated concrete technical artefacts and systems, referred to as tertiary retentions by Stiegler).

So we can ask: is it really true in general, as Ihde claims, that the same technical artefact in another use context or cultural setting becomes quite a different artefact (Ihde 1990, 144)? Is it really the case for instance that the Internet is quite a different thing in each different cultural context? Or, for that matter, the cell phone operating on either the Apple or the Android operating system (basically the only two options available today)? Is it not much more accurate to say on the contrary that these technologies impose their grammatological characteristics on cultures worldwide, indeed gradually reframing them in their own image? The many new and varied empowerments opened up by the Internet or the global adoption of cell phones notwithstanding, I think it cannot be denied that the general trend globally is that of an increased integration and uniformity of uses and a steady decline in diversity at all levels-social, cultural, psychological and even neural-due to the almost universal imposition of identical digital infrastructures and protocols under capitalist conditions, i.e. under the reign of calculation and the profit criterium. Peter Trawny for one has shown in great detail how enframing, or what he refers to as the Technology. Capital.Medium (TCM) universal, induces a process of subjectivation that is inherently

\footnotetext{
${ }^{6}$ During the encounter with Stiegler at the Radboud University of Nijmegen in January 2018, Ihde kept insisting on the obvious fact that pens and pencils can also be used as weapons and indeed are frequently used as such, more often than one would imagine as statistic data apparently suggest. Of course this holds for many other objects. In principle, any object can be turned into a weapon in human hands, or alternatively into an artistic 'objet trouvé'.
} 
normalizing and indifferentiating (Trawny 2017, 96-100), such that the only real difference left today between subjects-the only one that really 'counts'-is tending to become purely quantitative: the difference between rich and poor (ibid., 100).

And in that sense I'm not at all convinced by Ihde's persistent claim of contemporary postmodern technoculture as being pluricultural (ibid., 156). Instead what we perceive much more decisively is an ongoing equilization and synchronization of existences worldwide, and the rapid expansion of a global, increasingly automated capitalistic monoculture that peddles the same commodities everywhere and dictates its uses ever more insistently and successively through marketing techniques and ever smarter so-called 'addictive technologies', producing a generalized proletarianization and a global spread of identical and indeed increasingly addictive consumerist behavior patterns, as Stiegler rightly observes (Stiegler 2013, 27, 32). And it seems to me that instead of the "variant cultural embeddings' of technology (ibid., 144) highlighted by Ihde, we should acknowledge the much more dominant trend of a largely homogenizing technological enframing of cultures globally. In general, the thesis of multistability does not accord well with the ever increasing interwovenness, interdependence and interoperability of the digital networks and the devices connected to it. Of course image technologies present the affluent regions of the globe with a smörgåsbord of cultural, ethnic and other representations, and surely, cuisines, fashions, music and other marketable cultural expressions are commoditized and consumed all over the planet, again mostly among the affluent majority, but the net effect of this generalized commodification is the progressive elimination of genuine difference and a steady 'growing of the desert', to use Nietzsche's famous expression.

Be that as it may, the important thing to note is that the disruptive impact of technical becoming on human societies is genuinely epochal, Stiegler contends, instituting what Heidegger would understand as a mode of withdrawal of being, doing so in the sense that it suspends all extant social programs or all the existing understandings of being as Heidegger again would put it, but it thereby opens the possibility and equally the necessity of establishing a new epoch of being, i.e., a new mode of existence, a new way of life and a new culture (Stiegler 2011b, 11-12). In fact, what Heidegger analyzed in Being and Time as the broken hammer interrupting the smooth operation of hammering and thereby opening up Dasein to the 'worldhood of the world' as the 'totality of involvements' in which it is normally absorbed (Heidegger 2010, 116), should in that regard be repeated today at the level of the technical system, Stiegler suggests, which has become planetary since the emergence of enframing (Stiegler 2016b, 32).

What we experience today at this systemic and all-encompassing, planetary-wide level of, yes, 'Technology with a capital $\mathrm{T}$ ' is not so much an interruption anymore but a total disruption and therefore disorientation of the social and cultural systems by an ever accelerating technological juggernaut, a disruption that seems to frustrate any possibility of collective adoption and thus of establishing a new mode of collective existence that is truly desirable and worth living and that can transform the process of technical becoming from a blind and largely destructive and entropic geological factor into a more aware, more intelligent, constructive and negentropic one, or that is the claim and the greatest concern of Stiegler's whole philosophical enterprise.

However that may be, I want to maintain that it is important, particularly at the current moment when 'mankind has become astral', as Maurice Blanchot has put it (Stiegler 1998, 93), and our technological impact on the Earth system is becoming decisive for its very future, to admit the existence of a systemic and totalizing 'Technology with a capital T' and to start thinking it-and that is to say in its relation to the Earth system as our life support system, on which it ultimately depends but that also becomes more and more 
dependent on it. And this starting from the insight that we do not at all control this technical system but that it nonetheless allows us to control things, yet also to take care of them in ways that we still have to find out for the most part (cf. Lemmens 2018a).

It is of course true that concrete technical objects put concrete human practices in question, and it is perfectly fine for postphenomenology to focus exclusively-and if I may add: somewhat myopically-on these concrete practices and decide to deal only, 'more modestly and more pragmatically', in the words of Ihde, with 'questions of technologies' (Ihde 2016, 114), in the lower case and in the plural, but what we are confronted with in the emerging age of the Anthropocene and with an unprecedented urgency is exactly what Heidegger addressed in the 1950s as "the question concerning Technology" in the singular, with a capital T, indeed as the planetary 'event of appropriation' (Ereignis) of enframing as a singulare tantum, to use Heidegger's expression from The Principle of Identity (Heidegger 1969, 36), happening on and with the singular planetary body that is the Earth.

\section{Technology with a Capital T in the Context of the Anthropocene}

This is precisely the meaning, if we follow Stiegler, of the Anthropocene, and what it confronts humanity with like never before is not just 'the toxicity of its own development', as Stiegler puts it (Stiegler 2016b, 216), but the absoluteness and inescapability of its technical condition. The Anthropocene, I am inclined to think, is the true tragedy of our age, a tragedy in the sense of an unprecedented and totally unexpected encounter of humanity-and that is to say all of humanity despite the fact that it is first of all 'Western' humanity that unleashed the problem-with the dire consequences of its own technological hybris, and that is to say on a scale and with a gravity unimaginable to the ancient Greeks at the time they invented the violence of techne to conquer the overwhelming power of dike and started to bring and hold into the open what they called physis as aletheia (cf. Heidegger 2000, 171). Having lost any sense of the tragic though during our triumphant metaphysical conquest of what came to be called 'nature', we do not seem to be able to experience this tragic fate of ours. And that is exactly what is most tragic to us and our contemporaries, as Clive Hamilton also suggests in the preface to his book Defiant Earth, where he suggests that the greatest tragedy of our time is precisely 'the absence of a sense of the tragedy' (Hamilton 2017, x).

It is patently obvious that the Anthropocene has resulted from the continuous expansion of the planetary technical system that Heidegger started to call enframing (Gestell) in the 1950s and that we should now start to reconceptualize even more explicitly from a planetary, i.e., earth-systemic perspective as a truly geological sphere of its own. And that is to say: as the technosphere, as has recently been suggested by the American environmental and Earth scientist Peter Haff (Haff 2013). This technosphere should be thought in its relation to the biosphere and above all, I want to add, in its inextricable and decisive connection with what Pierre Teilhard de Chardin and Vladimir Vernadsky in the 1920s began to call the noosphere, by which they meant the increasingly impactful layer of thought (nous) surrounding the earth since the birth of scientific reason, yet without explicitly acknowledging its thoroughly technological constitution (Teilhard de Chardin 2008; Vernadsky 2012). It is on the future development of this planetary techno-noosphere that the future of the biosphere now crucially depends, the fate of the one determining the fate of the other.

The future survival of humanity requires a fundamental reframing of this techno-noosphere and this implies for philosophy of technology that it starts taking into account the 
earthly context of technology and technological change as well as the fact that this earthly Ur-Grund is itself an increasingly technologized, artificialized context. The claim that I want to make here is that that which has categorically been rejected by the empirical turn, above all by postphenomenology, as 'Technology with a capital T' should be reconsidered in terms of this techno-noosphere and should as such be rehabilitated as a serious and urgent object of philosophical reflection, and in my personal view as the prime object of philosophical reflection for a necessarily earth-oriented future philosophy of technology. And this calls again, therefore, for more broad-ranging and whole-oriented approaches in the philosophy of technology, not so much as a correction but as a complement to the now still dominant micro-level analyses of concrete artefacts and particular use contexts favored and promoted by the 'empirical turn' since the 1990s.

I have therefore proposed a 'terrestrial turn' in philosophy of technology which should consider technology not just empirically anymore, and not even only as the broad sociocultural and/or ontological phenomenon of classic philosophy of technology, but should think it even more bigger and theorize it explicitly in its planetary context and as a planetary phenomenon in its own right (Lemmens et al. 2017). I have no time here to delve more deeply into the requirements of such a philosophical program but one of the most important questions to be addressed by it, in my view, ${ }^{7}$ is how to conceive of the relation between the four principal geospheres (litho-, hydro-, and atmosphere but foremost the biosphere) and the technosphere, given the fact that technology is not just embedded in earth's ecology and energetic flux anymore but is increasingly becoming its prime animating factor, such that the future habitability of the earth is becoming the technological question par excellence.

This calls for a dialogue between philosophy of technology, earth system science (ESS), Gaia theory, cybernetics and the sciences of thermodynamics. Focusing on the noosphere, this program should also inquire into the ecological and eco-therapeutic potentials of the planetary-scale digital network technologies that constitute the current noosphere and fundamentally condition humanity's responsiveness and response-ability vis-à-vis the earth system (Lemmens 2018a). It should also critically engage with recent attempts to theorize the technosphere from an ESS perspective as the 'defining system of the Anthropocene' by the already mentioned Peter Haff (Haff 2017, 1), ${ }^{8}$ who emphasizes its autonomous nature and argues that it has an 'intrinsic agency' (ibid., 3), operating 'according to its own dynamics' (ibid., 7) yet depleting and destroying the natural geospheres on which it depends and thereby undermining its own conditions of existence (Haff 2013, 5). I only want to point out here that the technosphere as theorized in the context of ESS poses questions for philosophy of technology that hark back to, and thus forces philosophers of technology to reconsider, all those aspects of 'Technology with a capital $\mathrm{T}$ ' that have been discarded during the last decades.

One of the things philosophy of technology should question is Haff's naturalist and physicalist depiction of the technosphere and the lack of historical, anthropological and

\footnotetext{
7 Also keeping in mind Stiegler's assertion in volume one of The Automatic Society that the issue of energy as the play of entropy and negentropy within the earth system as modulated by the organological configurations of the technosphere will come to constitute the matrix of all future ecological and ecotechnological thought (Stiegler 2016a, 11).

${ }^{8}$ For Haff, the technosphere is 'a global system whose operation underpins the Anthropocene' (Haff 2014, 127 ) or in other words: 'The conditions of the Anthropocene arise from coordinated actions of humans and technology' (Haff 2017, 1).
} 
indeed ontological awareness it demonstrates. What is interesting about his ESS concept of the technosphere in my opinion, besides the fact that it considers technology in its totality as a terrestrial phenomenon, is that it offers a non-anthropocentric, 'outside' view of it, attributes autonomy to it vis-à-vis humans and theorizes it energetically or thermodynamically within the larger energetic matrix of the planet and its more ancient spheres. It also has its limitations though, for instance in that it understands the technosphere naturalistically in a purely physical (if not physicalist) sense without any recognition, to speak with Heidegger, of the decisively meta-physical 'nature' of technology (as a provocative mode of revealing of beings which has gained absolute hegemony today but is histori(c)ally contingent). It considers humans, however crucial to it, only ontically as functional parts of the technosphere and is ignorant about the human's onto-logical implication in the coming into being of this sphere (and that is to say, insofar as it claims their ontological freedom or openness to being in the Heideggerian sense), and it fails to appreciate what Stiegler has called the organological and pharmacological character of technology, in particular insofar as it involves its ambiguous entropic and negentropic potential (Stiegler 2016a, b, 8, 13-4).

A strong point of Haff's grand-scale analysis of technology in this respect is that it invalidates any anthropocentric and instrumentalist view of technology and instead exposes its autonomous and all-encompassing nature as a 'complex and leaderless' system resembling the biosphere (ibid., 132). ${ }^{9}$ Its weakness though consists in the fact that it remains blind to the ontological contingency of the 'Technology with a capital T'-technospheric process, whether conceived ontologically with Heidegger or organologically with Stiegler (Lemmens 2018b). Although Haff is right to point out the necessity of taking care of the needs of the technosphere vis-à-vis those of humans in finding a solution for reversing its depleting and destructive tendency (Haff 2013, 7-8), by simply opposing those needs to one another, he fails to acknowledge the crucial relation between fossil energy depletion and what Stiegler analyzes as the depletion of libidinal energy or the 'energy of existence' (Stiegler 2013, 91) which is typical of today's drive-based, fully computational consumerist capitalism that is ultimately responsible for the energy crisis. A conditio sine qua non of any possibility of taking care of the technosphere, and of its required 'reframing' (Lemmens \& Hui 2016), is the restoration of a libidinal economy and this is an organological question par excellence, having to do with the way the technosphere conditions human knowledge, attention and desire as negentropic potential (Stiegler 2016, 30).

Finally, as for the need to reframe the technosphere so as to move into what Stiegler has started to refer to recently as the Neganthropocene (Stiegler 2016a, b, 10), Peter Sloterdijk's suggestion of an emerging transformation in the essence of technology toward a more eco-oriented and bio-adaptive co-operation with the modi operandi of biological and biospheric processes, i.e., what he calls homeotechnics, is also important and deserves a more extensive examination for the negentropic potentials it might unlock (Sloterdijk 2017, 144ff). And with Yuk Hui, I would like to emphasize finally that a reframing or reconstruction of the technosphere should definitely not be conceived exclusively as a 'Western' affair but should explicitly include what he calls non-Western and non-modern 'cosmotechnics', i.e., other, also indigenous, ways of technical world-making such as that of the Polynesian or Amerindian collectives, which are based on ontologies-animist, totemist, analogist-that are totally different from the Western naturalism which has led us to conceive of the world

\footnotetext{
9 Which means that the 'Spaceship Earth' metaphor introduced by Richard Buckminster Fuller in the 1960 s is absolutely inappropriate while James Lovelock's 'Gaia' metaphor seems much more promising (cf. Stengers 2015, Latour 2018).
} 
as a giant standing reserve [Bestand], to use Heidegger's term (Hui 2016). As such, we should not only concentrate on the noosphere and the technosphere but also take into account what the Canadian anthropologist Wade Davis has called the 'ethnosphere' or 'the social web of life' surrounding the planet (Davis 2009, 2), but then explicitly understood as an ethno-noosphere and ethno-technosphere. ${ }^{10}$

However that may be, and to finally conclude, I think our time of planetary crisis requires of us to redirect our attention from the micro-level to the macro-level and from the empirical to the transcendental again. Humanity is birthing irresistably into a bigger world yet on a smaller, less stable, less predictable and less human-friendly planet (Rockström \& Klum 2015). As such it is put into question by its own technological adventure like never before, confronted with questions that are doubtlessly way too big for it but that it is nonetheless forced to deal with. But this has been humanity's lot since time immemorial as Sloterdijk stresses time and again (Sloterdijk 2013a, b?). ${ }^{11}$ I think philosophy of technology should put itself up to the task and dare to 'think big' again (Morton 2010, 20ff).

Open Access This article is licensed under a Creative Commons Attribution 4.0 International License, which permits use, sharing, adaptation, distribution and reproduction in any medium or format, as long as you give appropriate credit to the original author(s) and the source, provide a link to the Creative Commons licence, and indicate if changes were made. The images or other third party material in this article are included in the article's Creative Commons licence, unless indicated otherwise in a credit line to the material. If material is not included in the article's Creative Commons licence and your intended use is not permitted by statutory regulation or exceeds the permitted use, you will need to obtain permission directly from the copyright holder. To view a copy of this licence, visit http://creativecommons.org/licenses/by/4.0/.

\section{References}

Achterhuis, H. (2001). (2001) American Philosophy of Technology. The Empirical Turn. Bloomington: Indiana University Press.

Davis, W. (2009). The Wayfinders. Why Ancient Wisdom Matters in the Modern World. Toronto: Anansi Press.

Haff, P. (2013). Technology as a Geological Phenomenon. Implications for Human Well-Being. Geological Society London Special Publications, 395(1), 301-309.

Haff, P. (2014). Humans and Technology in the Anthropocene. Six Rules. The Anthropocene Review, 1(2), 126-136.

Haff, P. (2017). Being Human in the Anthropocene. The Anthropocene Review, 4(2), 1-7.

Hamilton, C. (2017). Defiant Earth. The Fate of Humans in the Anthropocene. Cambridge-Malden: Polity.

Heidegger, M. (1968). What is Called Thinking? New York: Harper \& Row.

Heidegger, M. (1969). Identity and Difference. New York: Harper \& Row.

Heidegger, M. (1977). The Question Concerning Technology and Other Essays. New York: Harper \& Row.

Heidegger, M. (1996). The Principle of Reason. Bloomington: Indiana University Press.

\footnotetext{
10 "Ethnosphere" is defined by Davis as "the sum total of all thoughts and intuitions, myths and beliefs, ideas and inspirations brought into being by the human imagination since the dawn of consciousness' (Davis 2009, 2). This 'logocentric' definition should not prevent us from thinking this ethnodiversity in the sense of a cosmodiversity and indeed technodiversity (cf. Hui 2016).

${ }^{11} \mathrm{Cf}$. 'Has thinking not always meant taking on the challenge that the excessive would appear concretely before us?' (Sloterdijk 2013a, 5) and: 'Humans can only advance as long as they follow the impossible... [...]. What is the human being if not an animal of which too much is demanded? [...] Whoever has not been seized by the oversized does not belong to the species of Homo Sapiens' (Sloterdijk 2013b, 442-3).
} 
Heidegger, M. (2000). Introduction to Metaphysics. New Haven and London: Yale University Press.

Heidegger, M. (2002). On Time and Being. Chicago: University of Chicago Press.

Heidegger, M. (2010). Being and Time. New York: SUNY Press.

Hui, Y. (2016). The Question Concerning Technology in China. An Essay in Cosmotechnics. Fallmouth: Urbanomic Media ltd.

Ihde, D. (1990). Technology and the Lifeworld. From Garden to Earth. Bloomington: Indiana University Press.

Ihde, D. (2012). Experimental Phenomenology, Second Edition: Multistabilities. New York: SUNY Press.

Ihde, D. (2016). Husserl's missing technologies. New York: Fordham University Press.

Kelly, K. (2010). What Technology Wants. New York: Penguin.

Kuhn, T. (1996). The Structure of Scientific Revolutions (3rd ed.). Chicago: The University of Chicago Press.

Latour, B. (2018). Facing Gaia. Eight Lectures on the New Climatic Regime. Cambridge-Malden: Polity.

Lemmens, P. (2017) Thinking Through Media Stieglerian Remarks on a Possible Postphenomenology of Media. Van Den Eede, Y, Irwin O’Neill, S. \& Wellner, G. (ed.). Postphenomenology and Media. Lanham: Lexington Books

Lemmens, P. (2018a). Re-Orienting the Noösphere: Imagining a New Role for Digital Media in the Era of the Anthropocene. Glimpse, 19, 55-64.

Lemmens, P. (2018b). From Ontology to Organology Heidegger and Stiegler on the Danger and Ambiguity of Technology and Technical Media', in Battin, J.M. \& Duarte, G. A, We Need to Talk about Heidegger. Essays Situating Martin Heidegger in Contemporary Media Studies. Berlin: Peter Lang

Lemmens, P., Blok, V., \& Zwier, J (2017) Toward a terrestrial turn in philosophy of technology Guest editor's introduction. Techne: Research in Philosophy and Technology, 21(2-3): 114-126

Lemmens, P. \& Hui, Y. (2017). Reframing the Technosphere. Peter Sloterdijk and Bernard Stiegler's Anthropotechnological Diagnoses of the Anthropocene. Krisis. Journal for Contemporary Philosophy 2017, Issue 2 .

Lyotard, J. F. (1984). The postmodern condition. A report on knowledge. Minneapolis: University of Minnesota Press.

Morton, T. (2010). The ecological thought. Cambridge: Harvard University Press.

Ricoeur, P. (1974). The Conflict of Interpretations. Essays in Hermeneutics. Evanston: North Western University Press.

Rockström, J., \& Klum, M. (2015). Big World Small Planet. Abundance Within Planetary Boundaries. Stockholm: Max Ström Publishing.

Rorty, R. (1991). Essays on Heidegger and Others. Cambridge: Cambridge University Press.

Rosenberger, R., \& Verbeek, P.-P. (2015). Postphenomenological Investigations Essays on Human-Technology Relations. Lanham: Lexington Nooks.

Sloterdijk, P. (2013). In the World Interior of Capital. For a Philosophical Theory of Globalization. Cambridge-Malden: Polity.

Sloterdijk, P. (2013). You Must Change Your Life. Cambridge-Malden: Polity.

Sloterdijk, P. (2017). Not Saved. Essays after Heidegger. Cambridge Malden: polity.

Stengers, I. (2015). In Catastrophic Times Resisting the Coming Barbarism. London: Open Humanities Press.

Stiegler, B. (1998). Technics and Time 1 The Fault of Epimetheus. Stanford: Stanford University Press.

Stiegler, B. (2009). Technics and time 2. Disorientation. Stanford: Stanford University Press.

Stiegler, B. (2010). For a New Critique of Political Economy. Cambridge-Malden: Polity.

Stiegler, B. (2011a). Technics and Time 3. Cinematic Time and the Question of Malaise. Stanford: Stanford University Press.

Stiegler, B. (2011b). The Decadence of Industrial Democracies. Disbelief and Discredit 1. CambridgeMalden: Polity.

Stiegler, B. (2012). 'The Theatre of Individuation. Phase-Shift and Resolution in Simondon and Heidegger', in De Boever, A. et al., Gilbert Simondon. Being and Technology. Edinburgh: Edinburgh University Press.

Stiegler, B. (2013). What Makes Life Worth Living. On Pharmacology. Cambridge-Malden: Polity.

Stiegler, B. (2014a). Symbolic Misery Vol. 1. The Hyperindustrial Society. Cambridge Malden: Polity.

Stiegler, B. (2015). Symbolic Misery Vol. 2. The katastrophè of the sensible. Cambridge-Malden: Polity. Stiegler, B. (2016a). Dans la disruption. Comment ne pas devenir fou? Paris: Le liens qui libérent.

Stiegler, B. (2016b). Automatic Society Vol. 1. The Future of Work. Cambridge-Malden: Polity.

Stiegler, B. (2017). Philosophizing by Accident. Interviews with Élie During. Edinburgh: Edinburgh University Press. 
Stiegler, B., \& Industrialis, A. (2009). Pour en finir avec la mécroissance. Paris: Flammarion.

Stiegler, B. \& Ars Industrialis. (2014b). The Re-Enchantment of the World The Value of Spirit Against Industrial Populism. London-New York: Bloomsbury.

Teilhard de Chardin, P. (2008). The Phenomenon of Man. New York: Harper Perennial.

Trawny, P. (2017). On Freedom. Technology. Capital. Medium. London-New York: Bloomington.

Van Den Eede, Y. (2017), 'The Mediumness of World. A Love Triangle of Postphenomenology, Media Ecology, and Object-Oriented Philosophy', in Van Den Eede, Y, Irwin, S. O. \& Wellner, G. (2017). Postphenomenology and Media. Essays on Human-Media-World Relations. Lanham: Lexington Books.

Van Den Eede, Y., Irwin O’Neill, S., \& Wellner, G. (Eds.). (2017). Postphenomenology and Media. Lanham: Lexington Books.

Verbeek, P.-P. (2005). What Things Do. Philosophical Reflections on Technology, Agency, and Design. University Park: Pennsylvania State University Press.

Vernadsky, V. (2012). 'The Transition From the Biosphere to the Noösphere'. 21st Century. SpringSummer, 2012, 10-31.

Publisher's Note Springer Nature remains neutral with regard to jurisdictional claims in published maps and institutional affiliations.

Pieter Lemmens Pieter Lemmens teaches philosophy and ethics at the Radboud University in Nijmegen, the Netherlands. He has published on themes in the philosophy of technology and new media and on human enhancement technologies, on the work of Martin Heidegger, Peter Sloterdijk and Bernard Stiegler, on the Anthropocene as well as on post-operaist Marxism (Hardt, Negri, Berardi) and topics related to philosophical anthropology and phenomenology. Current interests include the philosophy of technology in the age of the Anthropocene and the notion of the technosphere. 